\title{
Regenerative-Relational Tritangtu: Sundanese Triadic Transformation Model
}

\author{
Wanda Listiani, Heddy Shri Ahimsa-Putra, GR LonoLastoroSimatupang, \\ Yasraf Amir Piliang Media and Cultural Studies \\ Gadjah Mada University
}

\begin{abstract}
Tritangtu or Trinity mindset is a Sundanese and Minang community cosmology that consists of three entities (three patterns). Tritangtu as the local wisdom is also underlying the creative actors mental structure on making their works either in the form of performance, artifacts philosophy value, or in other cultural products in Indonesian community. This study used ethnographic method with data collection techniques were participant observation in-depth interviews and documentation. The object of study is the creative actors practice at the design field in Bandung.

The result of study pointed out the Sundanese Tritangtu transformation from the permanent structure to dynamic structure. The change in the structure is determined by the relation between the design elements forming structure with the global market segmentation. Lending Sundanese identity markers, especially the folk culture or the past traditions is regenerative efforts to harmonize the three patterns in encountering and winning the free-market competition in Indonesia.
\end{abstract}

Keyword: Tritangtu, Sundanese Triadic Transformation ModelAbstrak

Tritangtu atau pola pikir tritunggal merupakan kosmologi masyarakat Sunda dan Minang yang terdiri dari tiga entitas (pola tiga). Tritangtu sebagai kearifan lokal juga melatarbelakangi struktur mental pelaku kreatif dalam membuat karya baik berupa pertunjukan, nilai filosofi artefak maupun produk budaya lainnya di masyarakat Indonesia. Penelitian ini menggunakan metode etnografi dengan teknik pengumpulan data observasi partisipasi, wawancara mendalam dan dokumentasi. Obyek penelitian ini adalah praktik pelaku kreatif di bidang desain di Bandung. Hasil penelitian ini menunjukkan adanya transformasi tritangtu Sunda dari struktur yang tetap menjadi struktur dinamis. Perubahan struktur ini ditentukan oleh relasi antar struktur pembentuk unsur desain dengan segmentasi pasar global. Peminjaman penanda identitas Sunda khususnya budaya rakyat atau tradisi masa lalu merupakan upaya regeneratif dalam usahanya untuk harmonisasi pola tiga dalam menghadapi dan memenangkan persaingan pasar bebas di Indonesia.

Kata kunci : Tritangtu, Model Transformasi Triadic Sunda

\section{INTRODUCTION}

The Sundanese culture and art educational discourse about Tritangtu or Trinity mindset is a Sundanese and Minang community cosmology that consists of three entities (three patterns). According to Jakob Sumardjo (2010: 247-249) at the primordial community either Sundanese, Minangkabau, Batak, Malay, Nias, Mentawai, Madura (moor), Nusa Tenggara, South Moluccas, Dayak, North Sulawesi, Central Sulawesi, and South Sulawesi occupies the Upper World as entity that has women principle and Under World has men principle, the marriage consequence 
or harmony both occupies the human Middle World differently. In Sundanese community, the Upper World occupies the Trinity focus, while Minang community is focused on the Middle World. Tritangtu on the culture and art education in West Java is discoursed as the primordial community mindset while the contemporary community also have the Trinity mindset in the other form with three similar entities.

Tritangtu is one of Sundanese community local wisdoms. The term of local wisdom (Ayat Rohaedi in Rosidi, 2011:29) is translation of the local genius introduced by Quaritch Wales in 1948-1949, which means the ability of local culture on encountering the influence of foreign culture when both cultures are related. FD Bosch (Rosidi, 2011: 30) adds the importance of community members creativity in developing their culture in case of acculturation (come the outside influences that different from their own culture).

"... that outside influences (India) we do not swallow or imitate only, creating and formulating beliefs in contrast to those influence it, because has incorporated the existing elements in our own culture... JLA Brandes and NJ Krom showed that there were ten activities that have been held by the Javanese prior to the arrival of the In- dians, namely(1) puppet, (2) gamelan, (3) metric itself, (4) batik, (5) metal work, (6) its own currency, (7) shipping technology, (8) astronomy, (9) cultivation of rice on the wet field, (10) highly ordered system of government" (Rosidi, 2011, 30-32).

This study used ethnographic methods with data collection techniques were participant observation, in-depth interviews and documentation. The observation involved as creative actors in the design field was carried out in order that the researcher has knowledge and experience that are perceived by the informant. In-depth interviews was conducted on the creative actors have the design work with the hybridity characteristics and derived from the Sundanese ethnic. The documentation study to be supplement discourse particularly the work that has been published, sold and as reference of the culture and arts education in Indonesia.

\section{RESULT AND DISCUSSION}

The three's entities model have been existing for the other thousands of years initiated by Plato, Aristotle, the Stoics, Boethius, Bacon, Leiniz, Pierce, Husserl, Ogden and Richards and Morris. The following the three entities table in the table Sign Triadic Model.

Table 1. Sign Triadic Model

\begin{tabular}{|l|l|l|l|l|l|}
\hline No. & & $\begin{array}{c}\text { Sign } \\
\text { Vehicles } \\
(\mathbf{1})\end{array}$ & \multicolumn{1}{|c|}{ Sign } & \multicolumn{1}{|c|}{ Sense } & \multicolumn{1}{|c|}{ Referent } \\
\hline 1. & Plato (ca 400 B.C) & name & sound content & Idea, & thing \\
\hline 2. & Aristotle (ca 350 B.C) & [sign] & sound & affections & $\begin{array}{l}\text { Thing } \\
\text { (pragma) }\end{array}$ \\
\hline
\end{tabular}




\begin{tabular}{|l|l|l|l|l|l|}
\hline No. & & $\begin{array}{c}\text { Sign } \\
\text { Vehicles } \\
\mathbf{( 1 )}\end{array}$ & \multicolumn{1}{|c|}{ Sign } & \multicolumn{1}{|c|}{ Sense } & Referent \\
\hline 3. & Stoics (ca 250 B.C) & {$[$ sign] } & Semainon & $\begin{array}{l}\text { Semainome } \\
\text { non, lekton }\end{array}$ & $\begin{array}{l}\text { Object or } \\
\text { event }\end{array}$ \\
\hline 4. & Boethius (ca 500) & {$[$ word] } & Voice & concept & Thing \\
\hline 5. & Bacon (1605) & {$[$ word] } & Word & notion & Thing \\
\hline 6. & Leibniz (ca 1700) & {$[$ sign] } & Sign character & concept & Thing \\
\hline 7. & Peirce & sign & Representamen & interpretant & Object \\
\hline 8. & Husserl (1900) & sign & Expression & meaning & Thing \\
\hline 9. & $\begin{array}{l}\text { Ogden \& Richards } \\
\text { (1923) }\end{array}$ & - & Symbol & $\begin{array}{l}\text { Thought or } \\
\text { reference }\end{array}$ & Referent \\
\hline 10. & Morris & sign & Sign vehicle & significatum & denotatum \\
\hline
\end{tabular}

Source : (Noth, 1995:90)

In the sign Triadic model of Ogden and Richard for example have symbol entity, idea or references and guideline. These three entities and its structure are permanent as described below:

Figure 1. The Sign Model of Ogden and Richard

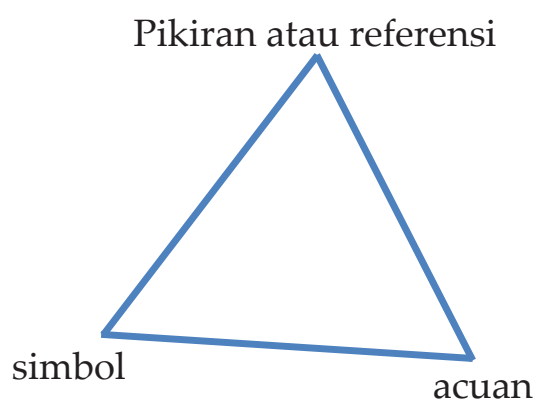

Source : (Sobur, 2004: 159)

Likewise its sign trichotomy models Charles Sanders Pierce, who has three entities namely representamen, object and interpretant.

Table 2. Pierce Three Trichotomies of Signs

\begin{tabular}{|l|l|l|l|l|}
\hline No. & Trichotomy & $\mathbf{1}$ & $\mathbf{2}$ & $\begin{array}{l}\mathbf{3} \\
\text { of the relation to } \\
\text { interpretant }\end{array}$ \\
\hline 1 & Firstness & qualisign & Icon & Rheme \\
\hline 2 & Secondness & Sinsign & Index & Dicent \\
\hline 3 & Thirdness & Legisign & symbol & argument \\
\hline
\end{tabular}

Sumber : (Noth, 1995:45) 
The Pierce trichotomy has form triangle and its structure is permanent as described below:

Figure 2. The Pierce's Trichotomy Model

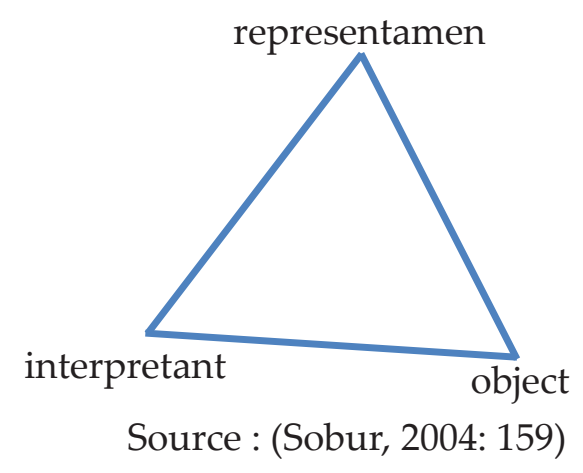

The other three's entities are Triadic structure of Hegel (Hegel, 2008: 18) that were subjective, objective, and absolute. As for the Triadic structure of Hegel (Hegel, 2008: 251), among others, logic of being (quality, quantity and measure); logic of essence (reflection within itself, appearance and actuality); logic of notion (subjectivity, objectivity and the idea). Structures Triadic was not terminated, such as sub being (quality) is further divided into (being, nothing and becoming). The following was the Hegel's logic science table:

Table 2. Pierce Three Trichotomies of Signs

\begin{tabular}{|c|c|c|c|c|}
\hline No. & Main Part & Heading & Subheading & Topic \\
\hline \multirow[t]{10}{*}{1.} & \multirow[t]{10}{*}{ The Logic of Being } & \multirow[t]{3}{*}{ Quality } & Being & $\begin{array}{l}\text { Being, Nothing, } \\
\text { Becoming }\end{array}$ \\
\hline & & & Determinate Being & \\
\hline & & & Being for self & \\
\hline & & \multirow[t]{4}{*}{ Quantity } & Quantity & \\
\hline & & & Quantum & \\
\hline & & & The Quantitative & \\
\hline & & & Relation & \\
\hline & & \multirow[t]{3}{*}{ Measure } & Specific Quantity & \\
\hline & & & Real Measure & \\
\hline & & & $\begin{array}{l}\text { The Becoming of } \\
\text { Essence }\end{array}$ & \\
\hline \multirow[t]{8}{*}{2.} & \multirow[t]{8}{*}{ The Logic of Essence } & \multirow{4}{*}{$\begin{array}{l}\text { Essence as } \\
\text { Reflection } \\
\text { Within Itself }\end{array}$} & Illusory Being & \\
\hline & & & Determinations of & \\
\hline & & & Reflection & \\
\hline & & & Ground & \\
\hline & & \multirow[t]{3}{*}{ Appearance } & Existence & \\
\hline & & & Appearance & \\
\hline & & & The Essential Relation & \\
\hline & & Actuality & The Absolute & \\
\hline
\end{tabular}




\begin{tabular}{|c|c|c|c|c|}
\hline No. & Main Part & Heading & Subheading & Topic \\
\hline & & & Actuality & \\
\hline & & & Absolute Relation & \\
\hline \multirow[t]{9}{*}{3.} & \multirow[t]{9}{*}{ The Logic of Notion } & \multirow[t]{3}{*}{ Subjectivity } & The Notion & \multirow[t]{9}{*}{$\begin{array}{l}\text { The Universal } \\
\text { Notion, } \\
\text { The Particular } \\
\text { Notion, } \\
\text { The Individual }\end{array}$} \\
\hline & & & The Judgement & \\
\hline & & & The Syllogism & \\
\hline & & \multirow[t]{3}{*}{ Objectivity } & Mechanism & \\
\hline & & & Chemism & \\
\hline & & & Teleology & \\
\hline & & \multirow[t]{3}{*}{ The Idea } & Life & \\
\hline & & & $\begin{array}{l}\text { The Idea of } \\
\text { Cognition }\end{array}$ & \\
\hline & & & The Absolute Idea & \\
\hline
\end{tabular}

Source : (Hegel, 2008: 252)

The Hegel's Triadic structure model has semi permanent structure that is derived from the three subsystems as the following models:

Figure 3. The Hegel's Triadic Structure Model

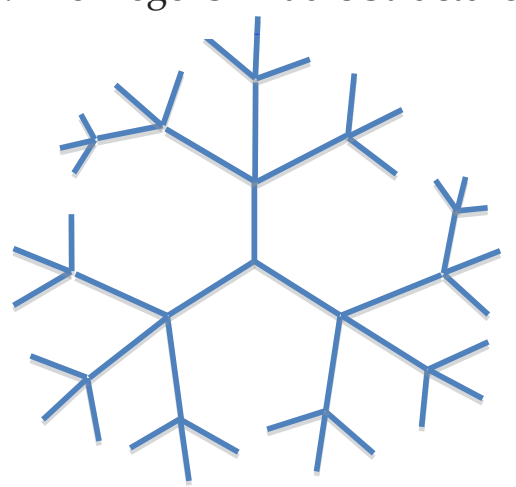

Source: Visualization by the writer, 201

From various entities three has developed before in the development of Western theories, particularly in Indonesia, the Sundanese has also three patterns that often referred to Tritangtu. Tritangtu (Sumardjo, 2011: 130-131) is the permanent Sundanese principle. Tritangtu or Trinity mindset (Sumardjo, 2010: 246) is found in Minang and Sundanese community cosmology that consists of the three entities (three patterns). This triangle relationship structure is described by JakobSumardjo as follows: 
Figure 4. The Pattern of Three or Tritangtu

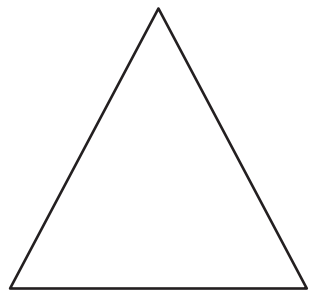

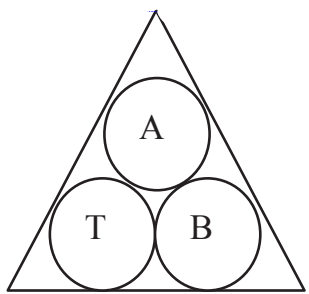

SUNDANESE

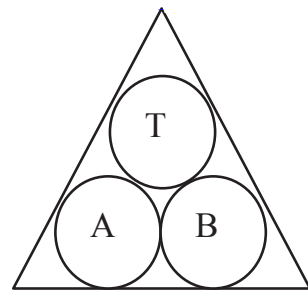

MINANG

Source: Sumardjo, 2010: 246

$$
\begin{aligned}
& \mathrm{A}=\text { Above World } \\
& \mathrm{B}=\text { Under World } \\
& \mathrm{T}=\text { Middle World } \\
& \mathrm{T}=\mathrm{L}-\mathrm{P}
\end{aligned}
$$$$
\mathrm{A}=\mathrm{Women}
$$$$
\mathrm{B}=\text { Men }
$$

Tritangtu Cosmology or triwarga also explained in Sanghyang Siksakandang Karesian which have equivalent levels in the earth (world).

Ini tri-tangtu di bumi. Bayukitapina[h] kaperbu, sabda kita pina[h]karama, h(e)dap kita pina[h] karesi. Ya tritangtu di bumi, ya kangken pineguh ning bwana ngara(n)na. Ini Triwarga di lamba. Wisnu kangken prabu, Brahma kangken rama, Isora kangken res. Nya mana tritan(g)tu pineguh ning bwana, triwarga hurip ning jagat (Danasasmita, 1987: 90).

Figure 5. Sundanese Tritangtu

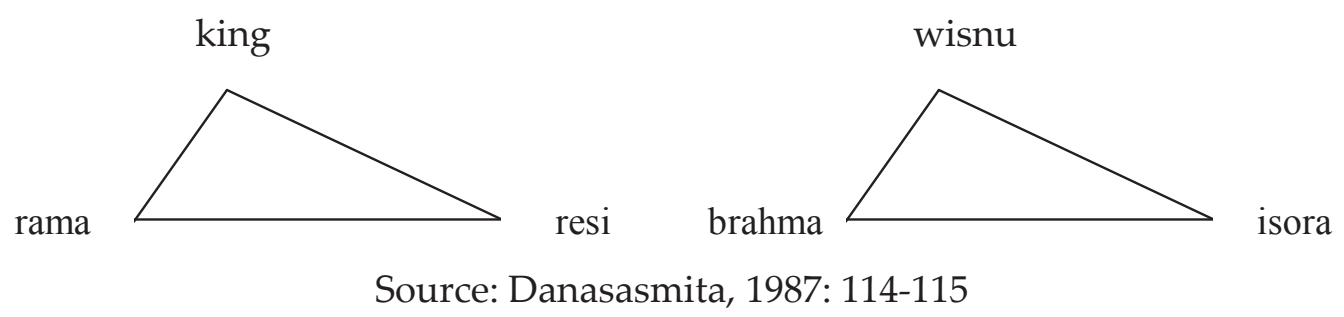

Translation:... threetermsin the world. Our prosperity is like the king, our said is like rama, our mind is like a hermit. These are tritangtu in life, called "peneguh dunia". It's life's triwarga.Vishnu is like prabu, Brahma is like rama, Isora likes age. That's why tritangtu become "peneguh dunia", triwarga become a life in the world (Danasasmita, 1987:114-115).

Cosmology or spatial universe (Darsa, 2011:11) in the teachings ofthepre-Islam- ic Sundanese described in the text Hayu Sang Hyang consisting of 3 arrangements, namely: (1) the composition of the underworld, sapta pala "seven countries", (2) buh loka is earth where we are today called pratiwi madya pada or "world in which human" and (3) the composition of the above world, sapta buana or buana pitu "seven heaven".

Tritangtu in its development experiences transformation. The transformation concept is understood in Structural Anthropology according to Heddy Ahimsa 
Putra (2001: 61-65) as the form transformation or altered in Javanese Ngoko. There is change in the surface level while in the deeper level the changes do not occur. Furthermore, Heddy Ahimsa Putra describes several transformation models i.e., First, the existence of differences and alteration, but the meaning or message contained are still similar. Second, the alteration on the surface is stil similar although the order is different. This is called by Heddy Ahimsa as structural transformation that is the form transformation the surface level only. Third, the alteration in the elements order that build the structure, but also the loss of certain elements in it and the core of messages delivered or structures within was not changed. Transformation is no other than code transformation. Explanation of cultural transformation in the West Java, especially among Sundanese is confirmed by JakobSumardjo as follows:

"... the story of culture transformation in West Java derived from the Sundanese primordial culture, to the Hindu-Sundanese, Islam and the modern culture, through its literary heritage, both oral or written. The stories of Sundanesemyth are transformed into poem stories. From the poem stories is transformed into Islam insight and modern insight. The Sundanese expression will not disappear from the earth surface, is the truth"(Sumardjo, 2011: 130)

Transformation is occurred in the Sundanese Tritangtu from permanent structure into dynamic structure. The structure changes is determined by the relation between the design elements forming structure with global market segmentation. The following is the transformation forms of
Sundanese Tritangtu from the Sundanese primordial culture to postmodern culture:

Figure 6. Sundanese Tritangtu Transformation

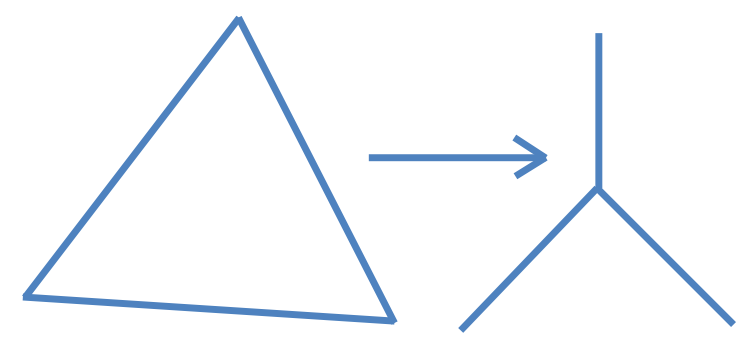

Source: Visualization by the writer, 2013

Lending the Sundanese identity markers particularly Tritangtu as part of the Sundanese primordial culture as regenerative efforts in attempt to always creating the conformity or harmony between the culture interests, to face the globalization and won the free market competition in Indonesia.

Figure 7. Regenerative-Relational Tritangtu

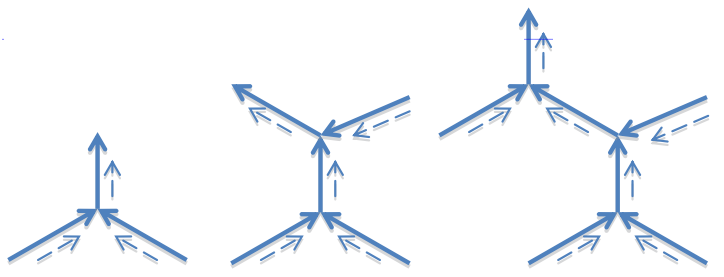

Source: Visualization by the Writer, 2013

The three's pattern transformation of Tritangtu that becoming regenerative-relational Tritangtu in Indonesia cultural and arts education discourse describes several things: First, there is change of culture view of the old Sundanese community and contemporary Sundanese community. Second, the economic competition affects the Sundanese community cultural behavior. Third, the Sundanese community people still maintain the conformity and harmony. The third form or the middle way shape as the form of tolerances 
on interaction with others. This showed by the pattern that always three. The similar three's entity at once is different from the initial system. Fourth, the subsystems that formed describe the structural transformation from static to dynamic.

\section{CONCLUSION AND RECOMMENDA-} TIONS

The results of study showed that Tritangtu as the local wisdom is also underlying the creative actors mental structures on creating the work both in the form of performance, artifacts, philosophical value, and other cultural products in Indonesian community. Transformation is occurred in the Sundanese Tritangtu from static structure into dynamic structure. The structure changes is determined by the relation between the design elements forming structure andglobal market segmentation. Lending the Sundanese identity marker particularly the people culture or the past tradition as regenerative efforts in the attempt to harmonize the three pattern on encountering and winning the free market competition in Indonesia. From the above result of research it is need to further research about the other cultures mindset with the cultural and art objects in Indonesia.

\section{REFERENCES}

AjipRosidi

2011 Kearifan Lokal dalam Perspektif Budaya Sunda, Bandung: Kiblat Buku Utama
Alex Sobur

2004 Semiotika Komunikasi, Bandung: Remaja Rosdakarya

HeddyShriAhimsa-Putra.

2001 Strukturalisme Levi-Strauss: Mitos dan Karya Sastra, Yogyakarta : Galang Press

Hegel, Georg Wilhelm Friedrich2008

Reading Hegel : The Introductions, Edited by Aakash Singh and Rimina Mohapatra, Melbourne : re.press

Jakob Sumardjo

2011 Sunda: Pola Rasionalitas Budaya, Bandung: Kelir

2010 Estetika Paradoks. Edisi Revisi, Bandung: SunanAmbu

2000 Filsafat Seni, Bandung: ITB

Leo, Racuh

1983 Hegel and The Human Spirit : A Translation of The Jena Lectures on The Philosophy of Spirit (1805-6) with Commentary, Detroit: Wayne State University Press

Noth, Winfried

1995 Handbook of Semiotics, Bloomington: Indiana University Press

Undang A Darsa.

2011 "Menelusuri Panorama Keagamaan Masyarakat Sunda" dalam Seminar Nilai-Nilai Sunda Wiwitan, Universitas Padjadjaran, Jatinangor 15 Juni 2011 